\begin{tabular}{c} 
International Journal of Engineering \& Technology, $7(3.10)(2018) 71-72$ \\
International Journal of Engineering \& Technology \\
SPC \\
Website: www.sciencepubco.com/index.php/IJET \\
Research paper \\
\hline
\end{tabular}

\title{
Financial Management System
}

\author{
Ms.S.Meena ${ }^{1}$, Mrs.S.Girija ${ }^{2}$, Mrs.S.Kayathri ${ }^{3}$ \\ ${ }^{l}$ Master of Computer Applications \\ ${ }^{2}$ Master of Computer Applications \\ ${ }^{3}$ Master of Computer Applications \\ *Corresponding author E-mail: meenaselvarajmca@ gmail.com
}

\begin{abstract}
The project entitled as "Financial Management System" The main objective is maintaining the company details and sends the daily report to the company manager. The admin can view the employee attendance details, employee registration details and sales de tails. This project contains two modules such as admin module and user modules. The admin can maintain employee details and sales details. In user modules, day by day update attendance details and product sales details in the system. So the admin can easily view product details and sales details and employee details in the system. The system can view day by day activities in the company process. The front end of the project is JSP and back end is MySQL.
\end{abstract}

Keywords: Employee Details; Sales Details; Product Details;

\section{Objective}

The project is used in companies for organizing employees inside organization. The main objective is maintaining the employee details, product details and sales details. This project is developed by web based application. The admin can view and add the employee attendance details, salary details, product details and daily profit or loss details. Using this system to reduce the paper work and saving the time consuming. First when a user comes to the company he has to be registered and in the manual system it is difficult to verify whether he is already registered. But in the computerized package it would be very easier to check all the customer details. This project contains two modules such as admin module, user modules. In admin module, the admin can maintain the product details and employee details and view the employee attendance details and salary details in the system. In user module, the user can view the product details and update the attendance details and sales details in the system. This project is reduced the manual process and easily maintains the product details in the system. In the existing system the transactions are done only manually but in proposed system we have to computerize all the banking transaction using the software financial management system. The system security is taken care of by a login form, which is allows only authorized users to utilize the system. The main aim/objective is to develop an effective system, which is fast, accurate, consistent, reliable, and flexible enough so that in can accommodate any further expansion.

\section{Introduction}

The project will maintaining the company details and sends the daily report to the company manager, the admin can view the employee attendance details, employee registration details and sales details, This project contains two modules such as admin module and user modules. The admin can maintain employee details and sales details. In user modules, day by day update attendance details and product sales details in the system. So the admin can easily view product details and sales details and employee details in the system, The system can view day by day activities in the company process.

\section{Problem Defintion}

This project is developed by web based application. The admin can view and add the employee attendance details, salary details, project details and daily profit or loss details. Using this system to reduce the paper work and saving the time consuming. This project contains three modules such as admin module, employee modules and customer modules. In admin module, the admin can maintain the company and employee details. so you can send message from home or office in a safe way. In customer module, the customer can login the system and receive project in the system. The message is automatically send to the admin Mobile.

\section{Module Description}

\subsection{Admin Module}

Login

Employee details

Attendance details

View Sales details

\subsection{User Module}

Registration

Login

Update attendance details

Sales details 


\subsection{Admin Module}

\section{Login}

The administrator login pages same as a user login page. The only difference is that the username and the password for this page are not maintained in the table. After filling all the fields the administrator can click the button to sign in

\section{Employee Details}

Admin can maintain employee details in the system. the details like emp name, id and position and salary and etc

\section{Attendance Details}

In this module, admin can view employee attendance details in the system. The attendance details such as staff name, staff position and in time, out time and staff leave details and so on. These details are stored in the database

\section{Sales Details}

In this module, the admin can view sales details like product name, product id, seller name and price, buyer name etc. these details are stored in the database

\subsection{User Module}

\section{Registration}

In this module every user have to login into our system otherwise user have to register their details into our website after complete registration user get a unique user id and password after that only user can login in our website

\section{Login}

The login page is used for logging in the site authenticate person allows for existing user. The user must first login to the site. After filling all the fields and the user can click the 'Submit' button to sign in

\section{Update Attendance Details}

In this module, user can update daily attendance details in the system. The attendance details such as staff name, staff position and in time, out time and staff leave details and so on. These details are stored in the database

\section{Update Sales Details}

In this module, the user can update day by day sales details like product name, product id, seller name and price, buyer name etc. these details are stored in the database

\section{Existing System}

The financial Managements are in existing system the works are only doing manual work. So taking time is very high and not accurate information is displayed. So the work is doing very low .The manpower work is high compare to proposed.. The system is used for daily activities such as booking, non delivery, out return, company details, and pickup centers. The company project data is maintained in the registers, the modification of data cannot do easily preparation of an up to data report is very complex, it require a lot of hard work and searching through the different register so as to condense the data for presentation.

DISADVANTAGES

Manual process is high.

Time is value than all, so sometimes not completed the task within the period.

Calculate salaries of the employees
To maintain details of the incoming couriers

\section{Proposed System}

This project will reduce the time also it will be of great help in carrying out company procedures and with this very objective in mind this online recruitment process has been made. In this proposed system admin will manage all such activities like product details, View the Employee information, sales details, View and update the Salary Report to particular Employee and that processing will using the project save time, reduce manpower and the biggest advantage of being it web based. . So the admin can easily view company details in the system. The user can update product sales details such as product name, price and buyer name and etc. Using this system to reduce the paper work and saving the time consuming.

\section{Advantages}

The system is such that is stands up to the user expectations like easy and faster retrieval of information.

The system will be accessible by only the authorized users. As information being the most crucial for the organization, then the safety of information is importation.

The reports will give the significant amount of time and effort invested by the employees time to time, by helping the management to know about their employee's capability.

\section{Conclusion}

This project is done by web-based and financial management System for the Group for a company. All employee information, new employees' details, relieved employees and salary report are totally managed by admin. So admin workloads are reduced this project. So admin was easily maintaining the company details in the system. That the information's are displayed are automatically changed to monitor. This Project is employing people, developing their resources, utilizing, maintaining and compensating their services in tune with the job and organizational requirement. There are two main modules are used such as admin module, user module. The admin module maintains the employee and product details in the system. The user just view the running process in the system, the process are staff attendance details and product details and view the status about the product. These are the modules running in the system. The front of the project is JSP package and to store the details in the database using MYSQL.

\section{References}

[1] Horstmann, C.S/ Cornell.G, 8th Edition, "Core Java: Volume 1 Fundamentals, 8th Edition, Pearson Education

[2] Horstmann, C.S/ Cornell.G, 7th Edition, "Core Java: Volume 1 Fundamentals, 8th Edition, Pearson Education

[3] Rob Ericsson and Jason Cline(2007)s, "SQL Server 2005", Charles River Media. 